\title{
Effects of selective-logging, litter and tree species on forests in the Peruvian Amazon: seed predation, seed pathogens, germination
}

\author{
Randall W. Myster \\ Biology Department, Oklahoma State University, Oklahoma City, OK 73107, USA \\ mysterrwm1@gmail.com \\ (Received for publication 24 March 2021; accepted in revised form 18 July 2021)
}

\begin{abstract}
Background: The Amazon basin contains mainly unflooded forests, and they are among the most important ecosystems in the world. Field experiments on seed processes are very important in order to understand the structure, function and dynamics of these forests.

Methods: Tree seeds of three species (Cecropia latiloba, Guarea macrophylla, Socratea exorrhiza) were set out in Amazon unlogged terra firme forest, in Amazon selectively-logged terra firme forest, in Amazon palm forest, and in Amazon white sand forest either on top of or beneath the litter layer, and after two weeks scored for seeds taken by predators, seeds destroyed by pathogens and seeds that germinated.

Results: I found both terra firme forests (unlogged and selectively-logged) lost most of their seed to predators and the least of their seed to pathogens, white sand forests lost the least of their seed to predators and the most of their seed to pathogens, and the fewest seeds germinated in both terra firme forests and in palm forest. More specifically (1) within unlogged terra firme forest addition of litter reduced seed predation but increased seed losses to pathogens and germination, and $C$. latiloba lost the most seeds to pathogens, (2) within selectively-logged terra firme forest seeds showed the same trends as unlogged terra firme forest but without significant effects, (3) within palm forest addition of litter reduced predation but increased losses to pathogens, and S. exorrhiza lost the least seeds to pathogens, and (4) within white sand forests addition of litter increased germination. Combining the results from all forests together, predators took most of the seeds, pathogens took most of the seeds that escaped predation, and most of the seeds that survived predation and pathogens germinated.

Conclusions: While such large losses of tree seed to predators and pathogens in these unflooded forests suggest limited recruitment, the variation demonstrated in these field experiments - among forest-types, among tree species, between litter situations on the forest floor - help to insure that recruitment does occur and that these unflooded forests continue to dominate the Amazon basin.
\end{abstract}

Keywords: Allpahuayo-Mishana National Reserve, Brosimum rubescens, palm, terra firme, white sand

\section{Introduction}

The Amazon basin contains some of the most important ecosystems in the world, significantly influencing the water, oxygen, carbon and other biogeochemical cycles for the entire planet. In order to understand the structure, function and dynamics of these key ecosystems, we need to know what controls the recruitment of their trees (Grubb 1977). In particular the post-dispersal (Myster 2017a) seed processes of seed predation, seed pathogens, and seed germination (Myster 2003, Myster 2015), play a critical role in determining the plant-plant replacements (Myster 2018) of the unflooded forests in 
the Amazon basin. Research in the Amazon has shown seed predation determines the fate of the majority of seeds (Bodmer 1991, Notman et al. 1996, Russo 2005, Paine \& Beck 2007) but even after suffering such large losses of seed, tree seedlings, tree saplings and mature trees do occur and regenerate these Amazon forests. This must be due to critical sources of variation (SOV) in how these mechanisms (seed predation, seed pathogens) and environmental tolerances (seed germination) work. While many of these SOV have been investigated in Amazon forests - for example variation among species, variation among microsites created by tree fall and conversion to agriculture, variation in the amount of litter, variation among different seasons, variation among different years and variation at different spatial scales (Bodmer 1991, Notman et al. 1996, Notman \& Gorchov 2001, Russo 2005, Vieira \& Scariot 2006, Paine and Beck 2007, Myster 2012, Myster 2014, Myster 2015, Myster 2017b) - we need more information in how seed mechanisms and tolerances work.

Most of the Amazon rainforest does not flood (Kalliola et al. 1991, Pitman et al. 2001) and terra firme forest (found on fertile clay or loam soils; Daly \& Prance 1989) is the most common unflooded Amazon forest-type. Other common unflooded forest-types include palm forests, found on moderately fertile soils that can be waterlogged, and white sand forests, found on infertile soils with large amounts of quartz (Tuomisto et al. 2003, Honorio 2006). In addition to these soil differences or perhaps because of them - these forests also vary in richness and physical structure (Stropp et al. 2011) where terra firme forest has the most number of species and the most complex structure, white sand forest has the least number of species and relatively simplest structure, and palm forest is between those two foresttypes in species richness and structure (Myster 2009). Among these unflooded forests, terra firme forest is most often logged either by clear-cutting, where all trees are cut and removed above a certain minimum size (e.g. $5 \mathrm{~cm}$ diameter at breast height [dbh]; Gorchov et al. 1993, Notman et al. 1996, Gorchov et al. 2004), or by selective-logging, where only trees of a select species (e.g. mahogany [Swietenia macrophylla]; Lambert et al. 2005, Grogan \& Galvao 2006) above a critical size (e.g. $50 \mathrm{~cm} \mathrm{dbh}$; Lambert et al. 2005) are cut and removed. While clear-cutting obviously changes terra firme forest dramatically, selective-logging can also change terra firme by, for example, creating gaps in the canopy, increasing road construction, and decreasing animal food resources and habitat which reduce pollination and seed dispersal (Jansen \& Zuidema 2001).

Therefore because of the importance of these forests, and the need for more investigation into critical SOV of their seed mechanisms and seed tolerances, I continue my past research into recruitment of Amazon unflooded forests (Myster 2012, Myster 2014, Myster 2017b) by conducting new field experiments on how selectivelogging, different tree seed species, and addition of litter interact to affect seed predation, seed pathogens, and germination in Amazon unlogged terra firme forest, in Amazon selectively-logged terra firme forest, in Amazon palm forest, and in Amazon white sand forest with litter interactions. I test these five hypotheses:

(1) Seed predators will take the majority of tree seeds put out in these Amazonian forests with terra firme forests (both selectively-logged and unlogged) having the greatest losses, white sand forests having the least, and palm forests between the two in losses (Bodmer 1991, Notman et al. 1996, Russo 2005, Paine \& Beck 2007, Myster 2009, Myster 2014, Myster 2017b).

(2) Seed pathogens will take the majority of tree seeds that predators do not take with palm forests having the greatest losses, white sand forests having the least, and terra firme forests (both selectively-logged and unlogged) between the two in losses (Myster 2017b).

(3) Most seeds that survive predators and pathogens will germinate, in all forests-types (Notman et al. 1996, Myster \& Everham 1999, Myster 2014).

(4) Adding litter on top of seeds will reduce predation but increase pathogenic effects and germination, again in all forest-types (Fenner 1985, Cintra 1997).

(5) Larger, heavier tree seeds will be taken by predators more than smaller, lighter tree seeds but there will be no seed-size trends for pathogens or germination (Pringle et al. 2007).

\section{Materials and Methods}

The study site was the Allpahuayo-Mishana National Reserve (AMNR) located $23 \mathrm{~km}$ from Iquitos, Peru in the Loreto Region of Maynas Province $\left(3.9^{\circ} \mathrm{S}\right.$, $73.6^{\circ} \mathrm{W}$; Hice et al. 2004; Saaksjarvi et al. 2004). AMNR was established in 1999, and is managed by Servicio Nacional de Áreas Naturales Protegidas por el Estado (http://www.sernanp.gob.pe/allpahuayo-mishana) and the Instituto de Investigación de la Amazonía Peruana (http://www.iiap.org.pe) with no hunting allowed. The Reserve covers 57,667 ha and lies between 110 and $180 \mathrm{~m}$ above sea level. The substrate is composed of alluvial and fluvial Holocene sediments from the eastern slopes of the Andes. Annual precipitation is approximately $2800 \mathrm{~mm}$ per year, and the rainy season is between October and May (Johnson 1976). The average temperature is relatively steady at $26{ }^{\circ} \mathrm{C}$. Terra firme forest, palm forest and white sand forest are common within the Reserve, and terra firme forest has also been selectively-logged there.

In May and early June 2017, 20 forest stands intermingled within AMNR were chosen - on the advice of my field assistant - consisting of: (1) five terra firme forest stands; (2) five palm forest stands; (3) five white sand forest stands; and (4) five terra firme forest stands that had been selectively-logged in 2010 by cutting and removing trees of Brosimum rubescens (locally called "palo de sangre"; Shirota et al. 1997) that were at least $60 \mathrm{~cm}$ in diameter (Jorge Chávez, pers. comm.). In each 
of the 20 forest stands a $100 \mathrm{~m}$ transect was set up with study microsites marked off every $20 \mathrm{~m}$, creating five microsites per stand and 100 microsites total. The bottoms of six plastic Petri dishes $(9 \mathrm{~cm}$ in diameter; Hulme 1994) were randomly placed in each microsite, three of those six dishes on top of the natural litter layer and three of those six dishes beneath the natural litter layer but on top of the soil. These litter treatments realise observed field conditions: (1) when a seed disperses on top of the litter layer and stays there; and (2) when a seed disperses on top of the litter layer but then falls down through the litter layer due to gravity over time which is more likely the heavier the seed. Bare areas without litter were very rarely observed in these forests, and so were not included in the treatments.

In each group of three dishes (three on top, and three beneath, the litter layer) 100 seeds in a 1-g seed pulp mass of Cecropia latiloba (Urticaceae: 0.002 g per seed; http://data.kew.org/sid, also see Myster 2015), five seeds of Guarea macrophylla (Meliacea: $0.6 \mathrm{~g}$ per seed; http://data.kew.org/sid) and five seeds of Socratea exorrhiza (Arecaceae: 3.4 g per seed; http://data.kew. org/sid) were placed in a separate dish which was randomly chosen. These three study tree species are frequent and abundant in terra firme, palm and white sand forests (Myster 2009; Myster 2017c). Five plastic seed mimics - made of the same size, shape and color of the real seeds or seed pulp mass - were also placed in each dish with holes in the bottom of the dishes to permit drainage in order to better understand seed removal. The seeds or seed pulp mass were collected, using gloves, locally from one individual tree of that species the same day they were put out. They were then visually inspected for damage or infestation, cleaned of fruit by hand (except for Cecropia latiloba) again using gloves and then floated to exclude nonviable seeds (except for Cecropia latiloba).

After two weeks in the field the percentage of seeds, either taken out of each Petri dish or still there but mainly eaten, were scored as eaten by predators. This scoring is justified because evidence of animal activity - such as chewed seeds, seed husks, and small mammal feces - was observed in the dishes (as in Blaney \& Kotanen 2001) and because the plastic seed mimics were not taken (Notman et al. 1996), both strongly suggesting that removal by abiotic agents - such as wind or rain - could be discounted. Thus I am assuming that seeds were removed by animals, and then either eaten or made nonviable in some other way by the animals that removed them (see Myster 2015). The remaining seeds or seed pulp mass, while still in their dishes, were then taken to an on-site shade house with sufficient light for germination (as in nature only those seeds that survive predation may attempt to germinate) and incubated in pots where litter was added on top of those dishes that were under litter in the field of the same type and density as in the field where they were taken from (Myster 1994). Pots were watered daily in amounts similar to natural rainfall and after five weeks seeds were examined under a dissecting microscope and scored as germinated, scored as destroyed by pathogens (where the seed did not germinate and had extensive fungal damage; Myster 2014; Myster 2017b), or other.

A single three-way analysis of variance (ANOVA) for seed loss due to predation, another one for seed loss due to pathogens and another one for seeds that germinated, with main effects of: (1) forest-type; (2) seed species; and (3) top/bottom of the litter layer, was not appropriate with this experimental design because treatments were not independently available and thus could not be randomly assigned in the field, i.e. foresttypes occur only in large stands, not in the small patches that would be necessary for a complete randomised experimental design. And so three separate one-way ANOVAs were first performed with forest-type (terra firme, selectively-logged terra firme, palm, white sand) as the only main effect where data were pooled across tree seed species and litter treatment within each foresttype. One of these ANOVAs used percent seed losses to predation as the response variable, one of these ANOVAs used percent seed losses to pathogens as the response variable, and one of these ANOVAs used percent seeds that germinated as the response variable. Furthermore because seeds may not have survived predation and/ or pathogens in some of the Petri dishes, which would have resulted in empty dishes and thus an unbalanced design in the field, ANOVAs were performed within the more robust general linear model (GLM with a binomial errors model:SAS 1985). Transformation of the data by arcsine is not needed to address normality when using GLM (Wilson et al. 2013).

Then a two-way ANOVA was performed for each forest-type with a main effect of litter (dish placed on top of the litter layer, dish placed on the soil underneath the litter layer with the litter layer then replaced on top of the dish), a main effect of tree species (Cecropia latiloba, Guarea macrophylla, Socratea exorrhiza) and an interaction effect of litter $x$ species. This ANOVA was performed three times - once for seeds lost to predators, once for seeds lost to pathogens, and once for seeds that germinated - for each of the four forest-types for a total of 12 two-way ANOVAs. For all ANOVAs if significance was found, means tests were conducted with the Tukey procedure (SAS 1985) to find which levels within treatments were most important in determining significance (bolded in the results).

\section{Results}

Forest-types differed significantly for seed losses to predation (Table 1: $\mathrm{df}=3, \mathrm{~F}=5.4, \mathrm{p}=0.03$ ) and white sand forests were lower than the other forest-types $\mathbf{4} \mathbf{4 6 . 1} \pm \mathbf{2 . 3} \%$ [mean \pm standard error] of seeds taken, $90.2 \pm 3.5 \%$ for unlogged terra firme, $73.3 \pm 1.9 \%$ for selectively logged terra firme, $81.8 \pm 4.4 \%$ for palm). Forest-types differed significantly for seed losses to pathogens (Table 2: $\mathrm{df}=3, \mathrm{~F}=9.9, \mathrm{p}=0.005$ ) and unlogged terra firme forests $(\mathbf{4 . 1} \pm 1.1 \%)$ and white sand forests $(43.1 \pm 5.2 \%)$ were most different from the other forest- 
TABLE 1: The percentage (mean \pm standard error) of the total seeds taken by seed predation among forest-types, among tree seed species, and in the no litter/litter treatment.

\begin{tabular}{lllll}
\hline Species & Terra firme & Logged terra firme & Palm & White sand \\
\hline Cecropia sp. & $94.1 \pm 1.5 / 60.3 \pm 2.6$ & $90.2 \pm 1.6 / 51.2 \pm 2.2$ & $91.7 \pm 1.5 / 55.4 \pm 2.3$ & $55.5 \pm 2.3 / 47.3 \pm 1.7$ \\
Guarea macrophylla & $96.2 \pm 1.2 / 95.5 \pm 1.7$ & $89.6 \pm 1.8 / 45.3 \pm 1.2$ & $93.1 \pm 2.4 / 65.8 \pm 2.2$ & $51.6 \pm 2.2 / 43.5 \pm 2.2$ \\
Socratea exorrhiza & $99.3 \pm 3.4 / 98.6 \pm 2.2$ & $85.3 \pm 3.3 / 80.5 \pm 1.3$ & $95.4 \pm 1.2 / 88.7 \pm 2.8$ & $40.5 \pm 2.3 / 39.2 \pm 1.5$ \\
\hline
\end{tabular}

TABLE 2: The percentage (mean \pm standard error) of the total seeds taken by seed pathogens among forest-types, among tree seed species, and in the no litter/litter treatment.

\begin{tabular}{lllll}
\hline Species & Terra firme & Logged terra firme & Palm & White sand \\
\hline Cecropia sp. & $6.2 \pm 1.4 / 33.5 \pm 1.2$ & $8.4 \pm 2.2 / 40.1 \pm 1.3$ & $9.2 \pm 3.1 / 40.6 \pm 3.4$ & $39.7 \pm 1.5 / 43.2 \pm 1.1$ \\
Guarea macrophylla & $4.4 \pm 3.3 / 5.2 \pm 1.4$ & $5.5 \pm 2.4 / 42.4 \pm 3.7$ & $4.4 \pm 1.3 / 30.1 \pm 1.8$ & $44.4 \pm 3.3 / 37.7 \pm 1.8$ \\
Socratea exorrhiza & $1.1 \pm 2.7 / 1.4 \pm 1.9$ & $11.9 \pm 1.7 / 15.4 \pm 3.2$ & $3.2 \pm 1.7 / 9.5 \pm 2.4$ & $51.3 \pm 2.6 / 45.2 \pm 1.8$ \\
\hline
\end{tabular}

types (logged $20.6 \pm 2.2 \%$, palm $16.9 \pm 1.8 \%$ ). Foresttypes differed significantly for seeds that germinated (Table 3: $\mathrm{df}=3, \mathrm{~F}=7.1, \mathrm{p}=0.01$ ) and unlogged terra firme $(\mathbf{1 . 2} \pm 0.2 \%)$ and palm $(\mathbf{2 . 5} \pm 0.8 \%)$ were lower than selectively logged terra firme $(5.2 \pm 1.1 \%)$ and white sand $(7.7 \pm 1.7 \%)$.

In unlogged terra firme forests seed predation was significantly different $(\mathrm{df}=1, \mathrm{~F}=2.5, \mathrm{p}=0.05$ ) between litter treatments $(96.1 \pm 7.2 \%$ no litter vs. $84.4 \pm 3.8 \%$ litter), seed pathogenic attack was significantly different $(\mathrm{df}=2, \mathrm{~F}=3.5, \mathrm{p}=0.02$ ) among tree species where Cecropia latiloba $(\mathbf{1 9 . 2 \pm 1 . 2 \% )}$ was higher than

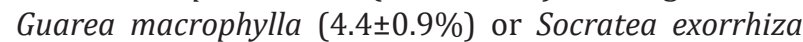
$(1.5 \pm 0.3 \%)$ and significantly different $(\mathrm{df}=1, \mathrm{~F}=4.2$, $\mathrm{p}=0.01)$ between litter treatments $(4.1 \pm 1.1 \%$ no litter vs. $13.4 \pm 2.1 \%$ litter), and seed germination was significantly different $(\mathrm{df}=1, \mathrm{~F}=2.6, \mathrm{p}=0.05)$ between litter treatments $(0.6 \pm 0.1 \%$ no litter vs. $3.7 \pm 1.1 \%$ litter). Selectively-logged terra firme forests showed the same results as unlogged terra firme forests.

In palm forests seed predation was significantly different ( $\mathrm{df}=1, \mathrm{~F}=2.6, \mathrm{p}=0.05$ ) between litter treatments $(93.1 \pm 5.9 \%$ no litter vs. $69.3 \pm 6.2 \%$ litter), seed pathogenic attack was significantly different $(\mathrm{df}=$ $2, \mathrm{~F}=3.3, \mathrm{p}=0.02$ ) among tree species where Socratea exorrhiza $(\mathbf{6 . 7 \pm 3 . 3 \% )}$ was lower than Cecropia latiloba $(25.4 \pm 3.8 \%)$ and Guarea macrophylla $(16.2 \pm 2.3 \%)$, and significantly different ( $\mathrm{df}=1, \mathrm{~F}=4.8, \mathrm{p}=0.01$ ) between litter treatments $(5.4 \pm 1.7 \%$ no litter vs. $27.7 \pm 3.7 \%$ litter). In white sand forests seed germination was significantly different ( $\mathrm{df}=1, \mathrm{~F}=2.5, \mathrm{p}=0.05$ ) between litter treatments ( $4.9 \pm 1.2 \%$ no litter vs. $8.4 \pm 2.1 \%$ litter).

\section{Discussion}

Among the four forest-types: both unlogged and selectively-logged terra firme forests lost the most seed to predators but lost the least seed to pathogens, white sand forests lost the least seed to predators but lost the most seed to pathogens, and the fewest seeds germinated in both terra firme forests and in palm forest. Within the two terra firme forests, litter reduced seed predation but increased both seed losses to pathogens and germination, and the smallest-seeded Cecropia latiloba lost the most seeds to pathogens. Within palm forests addition of litter again reduced predation but increased losses to pathogens, and Socratea exorrhiza lost the least seeds to pathogens. Within white sand forests litter increased germination. Selectively-logged terra firme forests followed the same trends as unlogged terra firme forests but without any significant effects.

Hypothesis one was supported by the results (most tree seeds were also taken by predators in a Singapore tropical forest; Wong et al. 1998) and selectively-logged forests had less predation than palm forests. Seed predation was greatest in unlogged terra firme forest and least in white sand forest, in medium intensity palm forest and in selectively-logged terra firme (close to $100 \%$ loss in Africa selectively-logged terra firme forest; Hall 2008). The terra firme results could be due to more predator species and abundance in those forests and/ or to a more specific search image for those predators (Gripenberg et al. 2019). Because most seeds were lost to predation (Myster 2014) the variation in how it operates - here for example among species, and on top of/under the litter layer - may be very important in determining

TABLE 3: The percentage (mean \pm standard error) of the total seeds germinated among forest- types, among tree seed species, and in the no litter/litter treatment.

\begin{tabular}{lllll}
\hline Species & Terra firme & Logged terra firme & Palm & White sand \\
\hline Cecropia sp. & $0.3 \pm 3.6 / 7.1 \pm 2.2$ & $2.2 \pm 1.4 / 6.5 \pm 2.1$ & $0.4 \pm 1.5 / 3.1 \pm 2.9$ & $3.4 \pm 3.1 / 10.9 \pm 2.4$ \\
Guarea macrophylla & $0.1 \pm 2.6 / 0.4 \pm 2.2$ & $5.1 \pm 2.4 / 10.3 \pm 1.7$ & $3.1 \pm 2.2 / 2.4 \pm 1.5$ & $3.3 \pm 2.4 / 15.2 \pm 2.2$ \\
Socratea exorrhiza & $0.5 \pm 1.3 / 1.2 \pm 1.6$ & $4.5 \pm 2.2 / 3.8 \pm 3.4$ & $1.1 \pm 2.4 / 2.7 \pm 2.5$ & $5.1 \pm 1.4 / 8.8 \pm 1.3$ \\
\hline
\end{tabular}


recruitment in these unflooded Amazon forests. Indeed because predation on top of the litter layer is mainly by vertebrates and predation below the litter layer is mainly by invertebrates (Grogan \& Galvão 2006), with time as seeds (especially dense, heavy seeds) fall down the litter layer due to gravity, predation may shift from being due primarily to vertebrates to being primarily due to invertebrates. Predation may also be due to invertebrates more than vertebrates for seeds of short dispersal (Notman \& Villegas 2005). Finally, low levels of seed predation in white sand forests may be related to its low animal richness and abundance (Myster 2009).

Hypothesis two was also supported by the results, with the caveat that it operated only on the seeds that survived predation. Most seeds germinated if they could escape predators and pathogens supporting Hypothesis three (common in tropical forests world-wide; VazquezYanes \& Oroza-Segovia 1983) and had complex interactions with forest-type, litter addition and tree seed species. Hypothesis four was supported mainly for the two terra firme forests and palm forest. Litter effects dominated seed losses to pathogens. Litter addition increased losses to pathogens in unlogged terra firme, in selectively-logged terra firme, and in palm forest. The species of these pathogens (which may have included the fungal pathogens Colletotrichum sp., Pythium sp. and Fusarium sp. found on tree seeds on landslides in Puerto Rico; see Myster 1997) may have been influenced by the species of neighboring trees (Grogan \& Galvão 2006). There were several interactive effects with tree seed species, that both supported and did not support Hypothesis five, as was seen in an Africa unflooded tropical forest (Hart 1995; Norghaner \& Newbery 2011). Outside of these hypotheses, results could also have been influenced by factors such as the ecological characteristics of the seed species used which are often associated with successional status, the biology and available of predators and pathogens, and the quality of seeds as it relates to fruiting phenology.

Results generally agree with other Amazon unlogged terra firme studies that found up to $90 \%$ of large seeds were lost to predators (60\% after 16 days; Russo 2005), mainly to mammals (Paine \& Beck 2007) with at most $12 \%$ scatter-hoarded but even those were eaten later. Further interactions were found in another unlogged Amazon terra firme forest where (1) seed predation rates were higher when monkey dung was present (Andresen 2002) and (2) invertebrate seed predation showed distance effects more than vertebrate seed predation (Terborgh et al. 1993). In Amazon unlogged terra firme studies using palm seeds and seedlings (1) seeds and seedlings of Astrocaryum murumera and Dipteryx micrantha survived better in gaps than in the understory (Cintra \& Horna 1997), (2) white-lipped peccaries decreased the density of Astrocaryum murumera seedlings (Silman et al. 2003), (3) Attalea maripa seed survivorship was unrelated to distance from individual fruiting palms (Salm 2006), (4) the removal of the exocarp and the mesocarp by large mammals increased Attalea maripa seed predation by beetles (Silvins and
Fragoso 2002), and (5) litter increased seed and seedling survivorship for Astrocaryum murumera but only seed survivorship for Dipteryx micrantha (Cintra 1997). Other Amazon unlogged terra firme studies showed that (1) larger seeds were taken by pathogens more than smaller seeds, germination was approximately $43 \%$ and pathogen loss was up to $75 \%$ depending on species (Pringle et al. 2007), (2) secondary dispersal was low (Culot et al. 2009), (3) post-dispersal palm seed predation was reduced under litter, but increased under thicker litter (Cintra 1997), and (4) after bat defecation seeds were eaten $8 \%$ per week with possible satiation (Romo et al. 2004).

In another study where terra firme forests were selectively-logged for Mahogany (Sweitenia macrophylla) (1) $40 \%$ of seeds were taken by predators and pathogens, and more seeds germinated (36\%) compared to an area where Mahogany was not logged (Grogan \& Galvão 2006) and (2) intensity of logging did not correlate with seed predation rates (Lambert et al. 2005). In a clearcut terra firme forest close to Iquitos (all trees $5 \mathrm{~cm} \mathrm{dbh}$ or greater were cut) (1) dispersal from the surrounding forest was rare, and regeneration came mainly from the seed bank and stumps with multiple sprouts (Gorchov et al. 2004) except for Cecropia sp. and Alchornea triplinervia (Gorchov et al. 1993), and (2) predation levels were the same as the primary forest 2-3 years after felling (Notman et al. 1996) with most predation occurring at the edge of forest and clear-cut and most seeds germinated (Notman et al. 1996).

In an Amazon study comparing both unflooded and flooded forest-types (Myster 2017b) (1) unlogged terra firme/white sand, and várzea (flooded by whitewater)/igapó (flooded by black-water for one month per year) were significantly different for seed predation, seed pathogens and germination, (2) in unlogged terra firme forest seed predators took most seeds regardless of species, (3) in palm forest species were different regardless of seed process, (4) in white sand forest seed predators took most seeds regardless of species, and (5) in várzea forest seed predators took most seeds but with some species differences. Looking at these foresttypes together, seed predation losses decreased as the forest became more stressed - perhaps by loss of soil fertility and/or by flooding with nutrient-poor water - while seed pathogens become more important with waterlogged soils and flooding. And seed loss variation among species was always a secondary factor for all effects. The higher plant species richness and complexity of unlogged terra firme (Valencia et al. 2004), and thus more seed predators, may explain the increase in seed predation. Likewise in species-rich várzea forest, there was more seed predation than in species-poor igapó forest at the same inundation time period. Within igapó forests more flooding lead to less predation, just as the wet palm forest had less predation than terra firme. For pathogens, standing water in the palm forest lead to the greatest losses, but increased flooding in igapó forests also lead to increasing loss of seeds to pathogens. 


\section{Conclusions}

Seed predation dominates in these unflooded forests (Bodmer 1991; Notman et al. 1996), and those losses decrease as forests become more stressed with loss of soil fertility (and/or with selective-logging; Paine \& Beck 2007). Litter effects dominate seed losses to pathogens and germination interactions with study area, litter and species were complex. Most seeds were lost to seed predators over all microsites. While addition of litter reduced seed predation, it increased losses of seed to pathogens (Fenner 1985). In addition, most seeds germinated if they could survive predators and pathogens (Myster 2014). With such intense predation and losses to pathogens in these forests, seed survival and germination is difficult. Differences in forest-type (perhaps related to soil fertility), as well as distributions of litter on the forest floor and variation in tree seed species may, nevertheless, facilitate recruitment. The complexities of forest recruitment, however, continue to be a major challenge for modelers who wish to predict the plant-plant replacements that cause Amazon forest community patterns, such as biodiversity. These results and other experiments in unlogged terra firme (Myster 2014) suggest other mechanisms or other SOV in the workings of these seed processes may play significant roles (Muller-Landau et al. 2008). Towards that goal, I continue to sample and conduct experiments in a one ha plot in igapó flooded forest in Peru for plant-plant replacements and recruitment processes (author, unpub. data).

\section{Competing interests}

The author declares that he has no competing interests.

\section{Acknowledgements}

I thank Luis Guerra for his help in the field and Dr. Juan Celedonio Ruiz Macedo, curator of the Universidad Nacional de la Amazonia Peruana herbarium, for his help in tree seed identification. I also thank T. Fahey, H. Asselin, S. Mikheyev, J. Powers, J. Dalling, H. Makinen, P. Campanello, C. Keller, C. Lusk, V. Pillar and C. Lacroix for commenting on a past draft of the manuscript.

\section{References}

Andresen,E.(2002). Primary seed dispersal by red howler monkeys and the effect of defecation patterns on the fate of dispersed seeds. Biotropica, 34, 261272. https://doi.org/10.1111/j.1744-7429.2002. tb00537.x

Blaney, C.S., \& Kotanen, P.M. (2001). Post-dispersal losses to seed predators: an experimental comparison of native and exotic old field plants. Canadian Journal of Botany, 79, 284-292. https://doi.org/10.1139/ b01-003

Bodmer, R.E. (1991). Strategies of seed dispersal and seed predation in Amazonian ungulates. Biotropica, 23, 255-261. https://doi.org/10.2307/2388202
Cintra, R. (1997). Leaf litter effects on seed and seedling predators of the palm Astrocaryum murumura and the legume tree Dipteryx micrantha in Amazonian forest. Journal of Tropical Ecology, 13, 709-725. https://doi.org/10.1017/S0266467400010889

Cintra, R., \& Horna, V. (1997). Seed and seedling survival of the palm Astrocaryum murumura and the legume tree Dipteryx micrantha in gaps in Amazonian forest. Journal of Tropical Ecology, 13, 257-277. https://doi.org/10.1017/S0266467400010440

Culot, L, Huuynen, M, Gerard, P \& Heymann, EW. (2009). Short-term post-dispersal fate of seeds defecated by two small primate species (Saguinus mystax and S. fuscicollis) in the Amazonian forest of Peru. Journal of Tropical Ecology, 25, 229-238. https:// doi.org/10.1017/S0266467409005860

Daly, D.C., \& Prance, G.T. (1989). Brazilian Amazon. In D.G. Campbell \& H.D. Hammond (Eds.). Floristic inventory of tropical countries: The Status of Plant Systematics, Collections, and Vegetation, plus Recommendations for the Future (pp. 401-426). New York: New York Botanical Garden.

Fenner, M. (1985). Seed ecology. New York, USA: Chapman and Hall. https://doi.org/10.1007/97894-009-4844-0

Gentry, A.A. (1993). Field guide to woody plants of northwest South America (Colombia, Ecuador, Peru). Washington, DC: Conservation International.

Gorchov, D.L., Cornejo, F., Ascorra, C. \& Jaramillo, M. (1993). The role of seed dispersal in the natural regeneration of rain forest after strip-cutting in the Peruvian Amazon. Vegetatio, 107/108, 339-349. https://doi.org/10.1007/978-94-011-1749-4_23

Gorchov, D.L., Palmeirim, J.M., Jaramillo, M. \& Ascorra, C.F. (2004). Dispersal of seeds of Hymenaea courbaril (Fabaceae) in a logged rain forest in the Peruvian Amazonian. Acta Amazonia, 34, 251-259. https:// doi.org/10.1590/S0044-59672004000200014

Gripenberg, S., Basset, Y., Lewis, O.T., Christopher, J., Terry, D., Wright, S.J., Simon, I., Fernandez, D.C., Cedeno-Sanchez, M., Rivera, M., Barrios, H., Brown, J.W., Calderon, O., Cognato, A.I., Kim, J., Miller, S.E., Morse, G.E., Pinzon-Navarro, S., Quicke, D.L.J., Robbins, R.K., Salminen J., \& Vesterinen, E. (2019). A highly resolved food web for insect seed predators in a species-rich tropical forest. Ecology Letters, 22, 1638-1649. https://doi.org/10.1111/ele.13359

Grogan, J., \& Galvão, J. (2006). Factors limiting postlogging seedling regeneration by big-leaf mahogany (Swietenia macrophylla) in Southeastern Amazonian Brazil, and implications for sustainable management. Biotropica, 38, 219-228. https://doi. org/10.1111/j.1744-7429.2006.00121.x

Grubb, P.J. (1977). The maintenance of species richness in plant communities: the importance of the regeneration niche. Biological Review of the 
Cambridge Philosophical Society, 52, 107-111. https://doi.org/10.1111/j.1469-185X.1977. tb01347.x

Hall, J.S. (2008). Seed and seedling survival of African mahogany (Entandrophragma spp.) in the Central African Republic: Implications for forest management. Forest Ecology and Management, 255, 292-299. https://doi.org/10.1016/j. forec0.2007.09.050

Hart, T.B. (1995). Seed, seedling and sub-canopy survived in monodominant and mixed forests of the Ituri forest, Africa. Journal of Tropical Ecology, 11, 443-459. https://doi.org/10.1017/ $\underline{\mathrm{S} 0266467400008919}$

Hice, C.L., Velazco, P.M., \&Willig, M.R. (2004). Bats of the Reserva Nacional Allpahuayo -Mishana, Northeastern Peru, with notes on community structure. Acta Chiromete, 6, 319-334. https://doi. org/10.3161/001.006.0210

Honorio, E.N. (2006). Floristic relationships of the tree flora of Jenaro Herrera, an unusual Area of the Peruvian Amazon. M.S. thesis, University of Edinburgh, Edinburgh, UK.

Hulme, P.E. (1994). Post-dispersal seed predation in grassland: its magnitude and sources of variation. Journal of Ecology, 82, 645-652. https://doi. org/10.2307/2261271

Jansen, P.A., \& Zuidema, P.A. (2001). Logging, seed dispersal by vertebrates, and natural regeneration of Tropical timber trees. In R. Fimbel, A. Grajal, \& J. Robinson (Eds.), The cutting edge. Conserving wildlife in logged tropical forests (pp 35-59). New York: Columbia University Press. https://doi. org/10.7312/fimb11454-006

Johnson, A.M. (1976). The climate of Peru, Bolivia, and Ecuador. In W. Schwerdtfeger (Ed.), Climates of Central and South America, World Survey of Climatology, (Vol. 12; pp. 147-210). Amsterdam: Elsevier Scientific.

Kalliola, RS, Jukka, M, Puhakkaa, M, \&Rajasilta, M. (1991). New site formation and colonizing vegetation in primary succession on the western Amazon floodplains. Journal of Ecology, 9, 877-901. https:// doi.org/10.2307/2261087

Lambert, T.D., Malcolm, J.R., \& Zimmerman, B.L. (2005). Effects of mahogany (Swietenia macrophylla) logging on small mammal communities, habit structure, and seed predation in the southeastern Amazon Basin. Forest Ecology and Management, 206, 381-398. https://doi.org/10.1016/j. forec0.2004.11.012

Muller-Landau, H.C., Wright, S.J., Calderon, O., Condit, R., \& Hubbell, S.P. (2008). Interspecific variation in primary seed dispersal in a tropical forest. Journal of Ecology, 96, 653-667. https://doi.org/10.1111/ j.1365-2745.2008.01399.x
Myster, R.W. (1994). Contrasting litter effects on oldfield tree germination and emergence. Vegetatio, $114,169-174$

Myster, R.W. (1997). Seed predation, disease and germination on landslides in Neotropical lower montane wet forest. Journal of Vegetation Science, 8, 55-64. https://doi.org/10.2307/3237242

Myster, R.W. (2003). Seed regeneration mechanisms over fine spatial scales on recovering Coffee plantation and pasture in Puerto Rico. Plant Ecology, 166, 199205. https://doi.org/10.1023/A:1023262109867

Myster, R.W. (2009). Plant communities of western Amazonia. The Botanical Review, 75, 271-291. https://doi.org/10.1007/s12229-009-9032-1

Myster, R.W. (2012). Spatial and temporal heterogeneity of light and soil water along a terra firme transect in the Ecuadorian Amazon. Canadian Journal of Forest Research, 42, 1-4. https://doi.org/10.1139/ $\underline{\mathrm{x} 11-168}$

Myster, RW. (2014). Interactive effects of flooding and tree fall gap formation on terra firme forest seed and seedling mechanisms and tolerances in the Amazon. Community Ecology, 15, 212-221. https:// doi.org/10.1556/ComEc.15.2014.2.10

Myster, R.W. (2015). Seed predation, pathogens and germination in primary vs. secondary Cloud forest at Maquipucuna Reserve, Ecuador. Journal of Tropical Ecology, 31, 375-378. https://doi. org/10.1017/S0266467415000127

Myster, RW.(2017a). Does the seed rain limit recruitment, regeneration and plant community dynamics? Ideas in Ecology and Evolution, 10, 1-12. https:// doi.org/10.4033/iee.2017.10.3.c

Myster, R.W. (2017b). Comparing and contrasting flooded and unflooded forests in Western Amazonia: seed predation, seed pathogens, germination. Community Ecology, 18, 169-174. https://doi. org/10.1556/168.2017.18.2.6

Myster, RW. (2017c). Forest structure, function and dynamics in Western Amazonia. Oxford, UK: Wiley-Blackwell. https://doi. org/10.1002/9781119090670

Myster, R.W. (2018). The nine classes of plant-plant replacement. Ideas in Ecology and Evolution, 11, 29-34. https://doi.org/10.4033/iee.2018.11.4.n

Myster, R.W., \& Everham III, E.M. (1999). Germination cues across the disturbance regime in the Puerto Rican rainforest. Tropical Ecology, 40, 1-10.

Norghauer, J.M., \& Newbury, D.M. (2011). Seed fate and seedling dynamics after masting in two African rain forest trees. Ecological Monographs, 81, 443469. https://doi.org/10.1890/10-2268.1

Notman, E., \& Gorchov, D.L. (2001). Variation in postdispersal seed predation in mature Peruvian 
low-land tropical forest and fallow agricultural sites. Biotropica, 33, 621-636. https://doi. org/10.1111/j.1744-7429.2001.tb00220.x

Notman, E., Gorchov, D.L., \& Cornejo, F. (1996). Effect of distance, aggregation and habitat on levels of seed predation for two mammal-dispersed neotropical rain forest tree species. Oecologia, 106, 221-227. https://doi.org/10.1007/BF00328602

Notman, E.M., \& Villegas, A.C. (2005). Patterns of seed predation buy vertebrate versus invertebrate seed predators among different plant species, seasons and spatial distributions. In P.M. Forget, J.E. Lambert, P.E. Hulme, \& S.B. Vander Wall (Eds), Seed fate. (pp. 55-75). CAB international. https:// doi.org/10.1079/9780851998060.0055

Paine, C.E.T., \& Beck, H. (2007). Seed predation by Neotropical rainforest mammals increases diversity in seedling recruitment. Ecology, 88, 3076-3087. https://doi.org/10.1890/06-1835.1

Pitman, N.C., Terborgh, J.W., Silman, M.R., Nunez, P.V., Neill, D.A., Ceron, C.E., Palacios, W.A. \& Aulestia, M. (2001). Dominance and distribution of tree species in upper Amazonian terra firme forests. Ecology, 82, 2101-2117. https://doi.org/10.1890/00129658(2001)082[2101:DADOTS]2.0.C0;2

Pringle, E.G., Alvarez-Loayzu, P. \& Terborgh, J. (2007). Seed characteristics and susceptibility to pathogen attack in tree seeds of the Peruvian Amazon. Plant Ecology, 193, 211-222. https://doi.org/10.1007/ s11258-006-9259-4

Romo, M., Tuomisto, H. \& Loiselle, B.A. (2004). On the density-dependence of seed predators in Dipteryx micrantha, a bat-dispersed rain forest tree. Oecologia, 140, 76-85. https://doi.org/10.1007/ s00442-004-1502-x

Romoleroux, K., Foster, R., Valencia, R., Condit, R., Balslev, H. \& Losos, E. (1997). Especies Lenosas (dap => 1 $\mathrm{cm}$ ) encontradas en dos hectáreas de un bosque de la Amazonia ecuatoriana. In R. Valencia, \& H.R. Balslev (Eds.), Estudios Sobre Diversidad y Ecologia de Plantas (pp. 189-215). Quito, Ecuador: Pontificia Universidad Católica del Ecuador.

Russo, S.E. (2005). Linking seed fate to natural dispersal patterns: factors affecting predation and scatterhoarding of Virola calophylla seeds in Peru. Journal of Tropical Ecology, 21, 243-253. https://doi. org/10.1017/S0266467405002312

Saaksjarvi, I., Haataja, S., Neuvonen, S., Gauld, I.D., Jussila, R., Salo, J., \& Burgos, A. (2004). High local species richness of parasitic wasps (Hymenoptera: Ichneumonidae; Pimplinae and Rhyssinae) from the lowland rainforests of Peruvian Amazonia. Ecological Entomology, 29, 735-743. https://doi. org/10.1111/j.0307-6946.2004.00656.x
Salm, R. (2006). Invertebrate and vertebrate seed predation in the Amazonian palm Attalea maripa. Biotropica, 38, 558-560. https://doi.org/10.1111/ j.1744-7429.2006.00163.x

SAS (1985). User's Guide: Statistics, Ver. 5. SAS Institute Inc. Cary, NC.

Shirota, O, Takizawa, K, Sekita, S, Satake, M, Hirayama, Y., Hakamata, Y., Hayashi, T. \& Yanagawa, T. (1997). Antiandrogenic Natural Diels-Alder-Type adducts from Brosimum rubescens. Journal of Natural Products, 60, 997-1002. https://doi.org/10.1021/ np9607215

Silman, M.R., Terborgh, J.W. \& Kiltie, R.A. (2003). White-lipped peccaries decreased the density of Astrocaryum murumra seedlings. Ecology, 84, 431-438. https://doi.org/10.1890/00129658(2003)084[0431:PROADR]2.0.CO;2

Silvins, K.M., \& Fragoso, .JM.V. (2002). Pulp handling by vertebrate seed dispersers increases palm seed predation by bruchid beetles in the northern Amazon.Journal of Ecology, 90, 1024-1032. https:// doi.org/10.1046/j.1365-2745.2002.00728.x

Stropp, J., van der Sleen, P., Assuncao, A.A., Silva, A.L., \& Ter Steege, H. (2011). Tree communities of whitesand and terra-firme forests of the upper Rio Negro. Acta Amazonica, 41, 521-544. https://doi. org/10.1590/S0044-59672011000400010

Terborgh, J., Losos, E., Riley, M.P., \& Bolanos-Riley, M. (1993). Predation by vertebrates and invertebrates on the seeds of five canopy tree species of an Amazonian forest. Vegetatio, 107/108, 375-386. https://doi.org/10.1007/978-94-011-1749-4 26

Tuomisto, H., Ruokolainen, K., \& Yli-Halla, M. (2003). Dispersal, environment and floristic variation of Western Amazonian forests. Science, 299, 241-244. https://doi.org/10.1126/science.1078037

Valencia, R., Foster, R.B., Villa, G., Condit, T.R., Svenning, J., Hernandez, C., Romoleroux, K., Losos, E., Magard, E., \& Balslev, S.L. (2004). Tree species distributions and local habitat variation in the Amazon: large forest plot in eastern Ecuador. Journal of Ecology, 92, 214-229. https://doi.org/10.1111/j.00220477.2004.00876.X

Vazquez-Yanes, C., \& Orozco-Segovia, A. (1983). Ecophysiology of seed germination in the tropical humid forests of the World: A review. In E. Medina, H.A. Mooney, \& C. Vazquez-Yanes. (Eds.), Physiological ecology of plants of the wet tropics (pp. 37-50) Proceedings of an international symposium, Mexico. https://doi.org/10.1007/978-94-0097299-5 5

Vieira, D.L.M., \& Scariot, A. (2006). Effects of logging, liana tangles and pasture on seed fate of dry forest tree species in Central Brazil. Forest Ecology 
and Management, 230, 197-205. https://doi. org/10.1016/j.foreco.2006.05.002

Wilson, E., Underwood, M., Puckrin, O., Letto, K., Doyle, R., Caravan, H., Camus, S., \& Bassett, K. (2013). The arcsine transformation: has the time come for retirement? http://www.mun.ca/biology/ dschneider/b7932/B7932Finall0Dec2010

Wong, T.C.M., Sodhi N.S., \& Turner, I.M. (1998). Artificial nest and seed predation experiments in tropical lowland rainforest remnants of Singapore. Biological Conservation, 85, 97-104. https://doi. org/10.1016/S0006-3207(97)00145-6 